\title{
LEADERSHIP VIA 5 FACTOR MODEL AND ROLES OF CYBER SECURITY, IT RISK MANAGEMENT - A CASE OF ALPHABET \& GOOGLE IN THE US
}

\section{SYLWIA GWOŹDZIEWICZ ${ }^{1}$, DINH TRAN NGOC HUY ${ }^{2}$, HONG VAN PHAM ${ }^{3}$ \& CHINH HONG NGUYEN ${ }^{4}$ \\ ${ }^{1}$ Jacob of Paradies University in Gorzow, Wielkopolski, Poland}

${ }^{2}$ Banking University HCMC, Ho Chi Minh City Vietnam, International University of Japan, Japan

${ }^{3}$ Dai Nam University, Vietnam

${ }^{4}$ Tha Academy of Finance, Hanoi, Vietnam

\begin{abstract}
Today, businesses want to grow, they must build their own "ecosystem", not only multi-industry but also diverse in terms of people, views, cultural characteristic Also, they need to pay attention to IT system and IT risk management program. After restructuring, Google manages Google Search, Maps, YouTube, Android and advertising. Meanwhile, other businesses such as Nest, Fiber, Google Capital, Google X are separated as subsidiaries under Alphabet's management. Google technologies that use cloud computing (including Gmail, Google Calendar, Google Docs, Google App Engine, Google Cloud Storage among others) and The development of Google News and Gmail are two examples of successful projects that emerged from $20 \%$ time. Multitasking but not hugging, it is the pinnacle of organizational management science when the division of labor is almost perfect at Google.

Movement of net profit in giant firms such as Alphabet \& Google will reflect the business health of technology system and the whole economy. Good business management requires us to consider the impacts of multi macro factors on net profit, and it contributes to promoting business plan and economic policies for economic growth and stabilizing macroeconomic factors. The results of quantitative research, in a seven factor model, show that the increase in inflation, GDP (increasing too much) and reducing cost has a significant effect on reducing Google net profit with the highest impact coefficient, the second is decreasing the net sale. This research finding and recommended policy also can be used as reference in policy for industrial technology system in many developing countries.
\end{abstract}

KEYWORDS: Google Net Profit; GDP Growth; Inflationary; SP500; Market Interest Rate, Cyber Security JEL: M21, N1

Received: Jun 08, 2020; Accepted: Jun 28, 2020; Published: Sep 03, 2020; Paper Id.: IJMPERDJUN20201034

\section{INTRODUCTION}

Today, businesses want to grow, they must build their own "ecosystem", not only multi-industry but also diverse in terms of people, views, cultural characteristics, or different cyber security management principles.

After restructuring, Google manages Google Search, Maps, YouTube, Android and advertising. Meanwhile, other businesses such as Nest, Fiber, Google Capital, Google X are separated as subsidiaries under Alphabet's management. Multitasking but not hugging, it is the pinnacle of organizational management science when the division of labor is almost perfect at Google. 
In the context that GDP growth in US has been stable and slightly increases during 2014-2019 and China-Trump war affected stock market, it is necessary to evaluate impacts of seven (7) internal and external macro economic factors on Google performance, esp. Net profit. From these analytical results, we could suggest bank and government policies to encourage and stabilize the growth of technological system and stock market in US and other countries such as Vietnam.

Looking at the below chart, we find out that Alphabet-Google net profit moves in the same trend with SP500, although it fluctuates in a higher range than GDP.

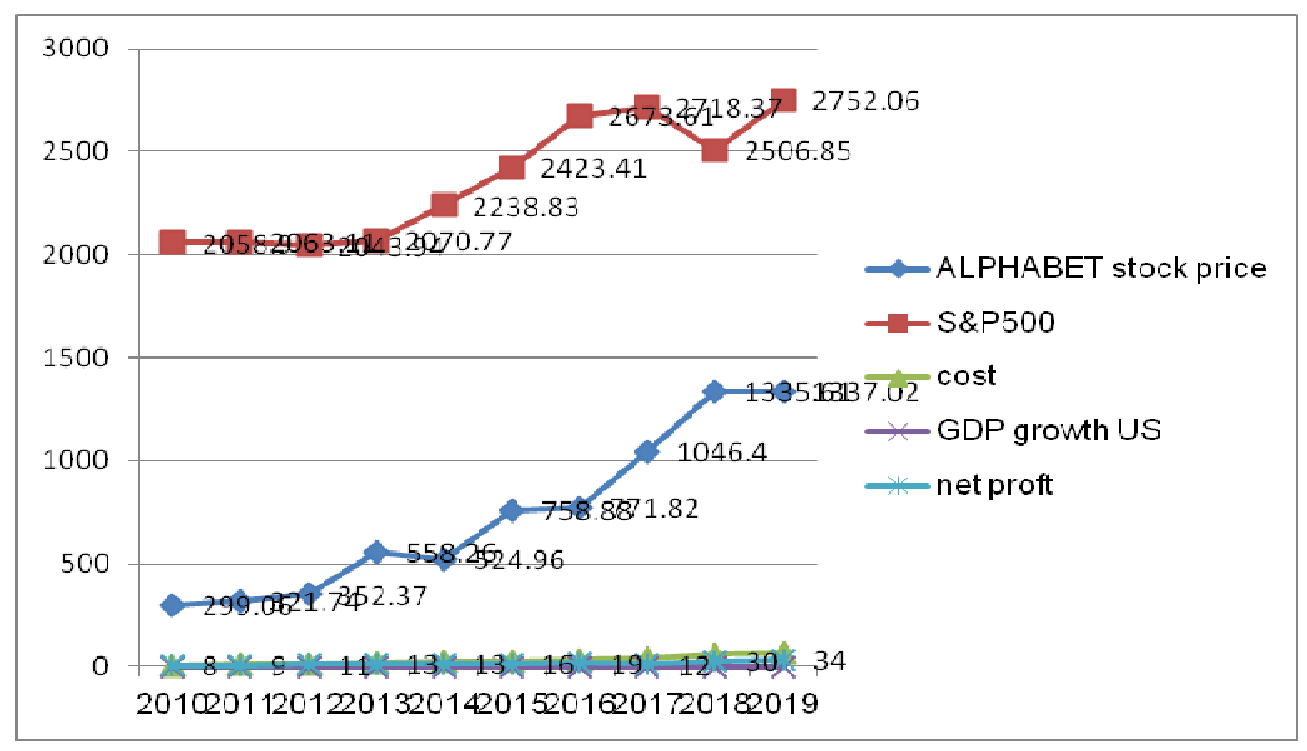

Figure 1

This study will calculate and figure out the impacts of seven (7) macro economic factors such as inflation, GDP growth, market interest rate, stock price, S\&P500 and lending rate on Alphabet-Google net profit.

The paper is organized as follows: after the introduction it is the research issues, literature review and methodology. Next, section 3 will cover methodology and data and section 4 presents main research findings/results. Section 5 gives us some discussion and conclusion and policy suggestion will be in the section 6 .

\section{BODY OF MANUSCRIPT}

\section{Research Issues}

The scope of this study will cover:

- Issue 1: What are the correlation and relationship among many economic factors: Alphabet-Google net profit, interest rate, exchange rate, inflation, S\&P 500 and GDP growth?

- Issue 2: What are the impacts of above 7 macro economic factors on Alphabet-Google net profit?

- Issue 3: Based on above discussion, we recommend some solutions regarding to commercial bank management in incoming period.

- Issue 4: We will answer the question of how cyber security should be shaped in the era of new technologies development.

This paper also tests two (2) below hypotheses: 
- Hypothesis 1: An increase in lending rate will make Alphabet-Google net profit declines.

- Hypothesis 2: An increase in inflation can increase pressure in Alphabet-Google net profit.

- Hypothesis 3: The development of new technologies must be related to investments in cyber security

\section{Literature Review}

Lina (2012) indicated that both the change of inflation rate and the growth rate of money supply (M2) are positive but insignificant to the banking industry stock return, the exchange rate is positive and significant to banking industry stock return and interest rate is negative and significant to banking industry stock return. Next, Sadia and Noreen (2012) found out exchange rate, and Short term Interest Rate have significant impact on Banking index. Macroeconomic variables like Money Supply, Exchange Rate, Industrial Production, and Short Term Interest Rate affects the banking index negatively where as Oil prices has a positive impact on Banking index.

Manisha and Shikha (2014) stated that Exchange rate, Inflation, GDP growth rate affect banking index positively whereas Gold prices have negative impact on BSE Bankex but none of them have significant impact on Bankex. Then, Winhua and Meiling (2014) confirmed that macroeconomic do have a substantial influence to the earning power of commercial banks.

Krishna (2015) investigated the nature of the causal relationships between stock prices and the key macro economic variables in BRIC countries. The empirical evidence shows that long-run and short-run relationship exists between macro economic variables and stock prices, but this relationship was not consistent for all of the BRIC countries. And Kulathunga (2015) suggested that all macroeconomic factors influence the stock market development. More precisely, volatile inflation rate and exchange rate together with higher deposit rate have curtailed the stock market development in Sri Lanka. Moreover, positive optimism created by the economic growth and the stock market performance during the previous periods tend to enhance stock market performance. Moreover, Duy (2015) mentioned through the evolution of interest rates and the VNI could see that the relationship between these two variables in the period 2005-2014 is the opposite. This relationship is shown in specific periods of the year the stock market proved quite sensitive to interest rates. When interest rates are low or high but the bearish stock market rally, and vice versa when the high interest rates the stock market decline.

Last but not least, Quy and Loi (2016) found that 3 economic factors (inflation rate, GDP growth rate, and exchange rate) impact significantly on real estate stock prices; but the relationship between 10-year Government bond yield and trading volume, and real estate stock prices was not found. Ahmad and Ramzan (2016) stated the macroeconomic factors have important concerns with stocks traded in the stock market and these factors make investors to choose the stock because investors are interested to know about the factors affecting the working of stock to manage their portfolios. Abrupt variations and unusual movements of macroeconomic variables cause the stock returns to fluctuate due to uncertainty of future gains.

Until now, many researchers have been done in this field, however, they just stop at analyzing internal macroeconomic factors on net profit. 
Within the scope of this paper, we measure impacts of both internal and external macro factors on AlphabetGoogle net profit and suggest policies for bank system, government, Ministry of Finance, FED and relevant government bodies. We also analyze data throughout time series from 2014-2019.

\section{METHODOLOGY AND DATA}

This research paper establishes correlation among macro economic factors by using an econometric model to analyze impacts of seven (7) macro economic factors in Vietnam such as: GDP growth, inflation, interest rate, exchange rate, on Alphabet-Google net profit.

In this research, analytical method is used with data from the economy such as inflation in US and market interest rate, GDP growth rate, lending rate. Data are included from 2014 -2019 with semi-annual data (10 observations in total). Data is estimated based on exchange rate and lending interest rates of commercial banks (average calculation). S\&P 500 index data is from USA Stock exchange, data source (inflation, GDP) is from Bureau of Statistics. Beside, econometric method is used with the software Eview. It will give us results to suggest policies for businesses and authorities.

We build a regression model with Eview software to measure impacts of factors. Alphabet-Google net profit is a function with 7 variables as follows:

$\mathrm{Y}(\mathrm{MBB}$ stock price $)=\mathrm{f}(\mathrm{x} 1, \mathrm{x} 2, \mathrm{x3}, \mathrm{x4}, \mathrm{x5}, \mathrm{x6}, \mathrm{x7})=\mathrm{ax1}+\mathrm{bx2}+\mathrm{cx} 3+\mathrm{dx} 4+\mathrm{ex} 5+\mathrm{fx} 6+\mathrm{gx} 7+\mathrm{k}$

With: $\mathrm{x} 1$ : GDP growth rate $(\mathrm{g}), \mathrm{x} 2$ : inflation, $\mathrm{x} 3$ : VN Index, $\mathrm{x} 4$ : lending rate, $\mathrm{x} 5$ : risk free rate (Rf), x6: USD/VND rate; $x$ 7: S\&P500

Beside, this paper also uses analytical and general data analysis method to measure and generate comments on the results, then suggest policies based on these analyses.

\section{MAIN RESULTS}

\section{General Data Analysis}

First of all, the below chart 1 shows us that Y has a positive correlation with GDP growth:

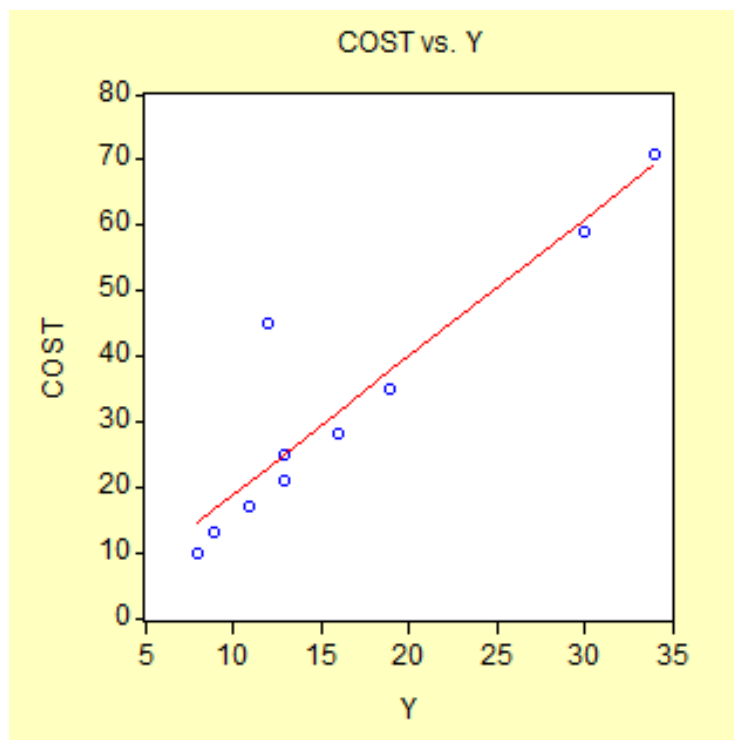

Chart 1: Net Profit (Y) vs. Cost (C). 

A Case of Alphabet \& Google in the US

Next we find out that, based on the below scatter chart, Y (Alphabet-Google net profit) has slightly positive correlation with inflation $(\mathrm{CPI})$.

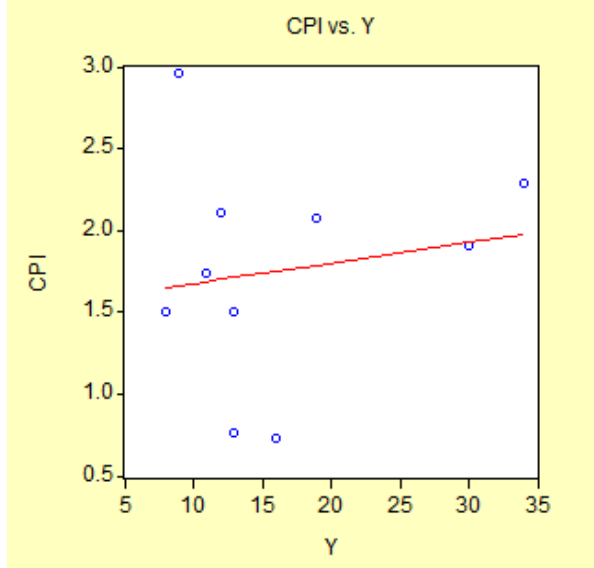

Chart 2: Alphabet-Google Net Profit (Y) vs. Inflation (CPI).

Looking at the below chart 3, we also recognize that Alphabet-Google net profit (Y) and GDP growth have positive correlationship.

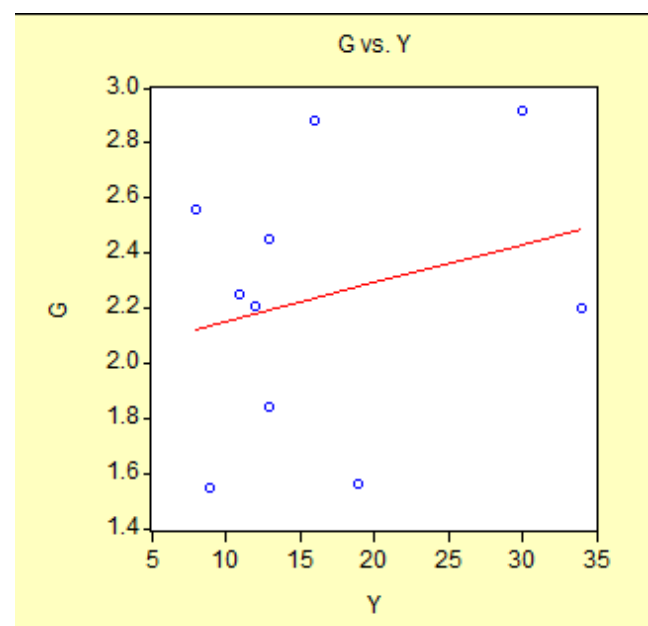

Chart 3: Y vs. GDP Growth.

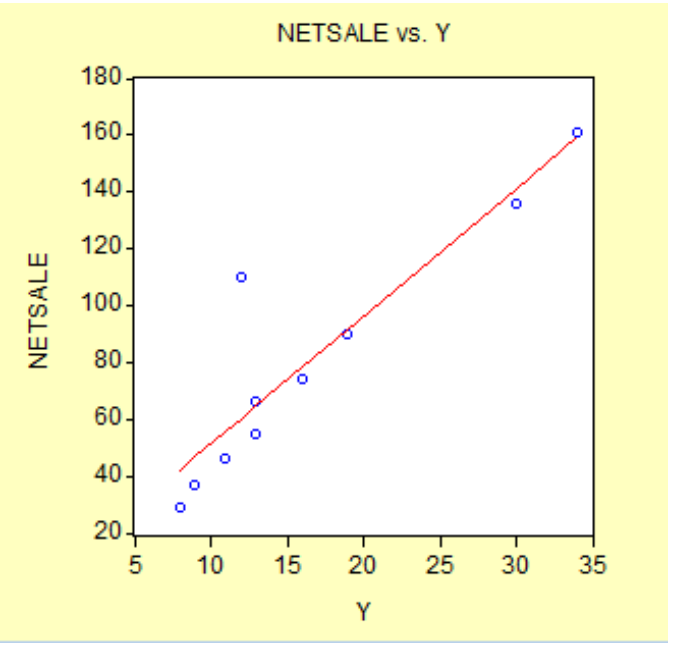

Chart 4: Y vs. Sale. 
We see that, Alphabet-Google net profit (Y) and sale have positive correlation:

On the other hand, we could see statistical results with Eview in the below table with 7 variables:

Table 1: Statistics for Macro and Micro Economic Factors

Unit: \%

\begin{tabular}{|l|c|c|c|c|c|c|c|c|}
\hline & Net profit & Net sales & Cost & $\begin{array}{c}\text { ALPHAB } \\
\text { ET stock } \\
\text { price }\end{array}$ & $\begin{array}{c}\text { Lending } \\
\text { rate US }\end{array}$ & $\begin{array}{c}\text { GDP } \\
\text { growth - } \\
\text { US }\end{array}$ & $\begin{array}{c}\text { Inflatio } \\
\text { n US } \\
\text { (CPI) }\end{array}$ & S\&P500 \\
\hline Mean & 80.40 & 16.50 & 32.40 & 730.61 & 0.04 & 2.24 & 1.76 & 2354.99 \\
\hline Median & 70 & 13 & 26.5 & 658.57 & 0.0325 & 2.23 & 1.825 & 2331.12 \\
\hline Maximum & 161 & 34 & 71 & 1337.02 & 0.0525 & 2.92 & 2.96 & 2752.06 \\
\hline Minimum & 29 & 8 & 10 & 299.06 & 0.0325 & 1.55 & 0.73 & 2043.94 \\
\hline Standard dev. & 43.663 & 8.810 & 20.228 & 395.032 & 0.008 & 0.485 & 0.680 & 294.931 \\
\hline
\end{tabular}

Looking at the above table, we recognize that standard deviation of stock price rate andSP500 are the highest values. Whereas standard deviation of GDP growth and lending rate are the lowest values.

If we want to see correlation matrix of these 8 macro variables, Eview generate the below result in table 2:

Table 2: Correlation Matrix for 8 Macro-Economic Variables (GDP Growth, Inflation in US, Market Interest Rate, Risk Free Rate, Exchange Rate and Alphabet-Google Net Profit)

\begin{tabular}{|c|c|c|c|c|c|c|c|c|c}
\hline \multicolumn{9}{|c}{ Correlation Matrix } \\
\hline & Y & NETSALE & STOCKPRICE & SP500 & R & G & CPI & COST \\
\hline Y & 1.000000 & 0.908735 & 0.880734 & 0.813094 & 0.905820 & 0.251056 & 0.162261 & 0.918447 \\
\hline NETSALE & 0.908735 & 1.000000 & 0.981436 & 0.964713 & 0.930727 & 0.227378 & 0.202016 & 0.998309 \\
\hline STOCKPRICE & 0.880734 & 0.981436 & 1.000000 & 0.935665 & 0.910754 & 0.309350 & 0.159689 & 0.978552 \\
\hline SP500 & 0.813094 & 0.964713 & 0.935665 & 1.000000 & 0.832833 & 0.173181 & 0.093920 & 0.954331 \\
\hline R & 0.905820 & 0.930727 & 0.910754 & 0.832833 & 1.000000 & 0.251969 & 0.358286 & 0.949642 \\
\hline G & 0.251056 & 0.227378 & 0.309350 & 0.173181 & 0.251969 & 1.000000 & -0.612037 & 0.233762 \\
\hline CPI & 0.162261 & 0.202016 & 0.159689 & 0.093920 & 0.358286 & -0.612037 & 1.000000 & 0.221519 \\
\hline COST & 0.918447 & 0.998309 & 0.978552 & 0.954331 & 0.949642 & 0.233762 & 0.221519 & 1.000000 \\
\hline
\end{tabular}

The above table 2 shows us that correlation among 8 macro variables. An increase in stock price and increase in CPI might lead to an increase in Alphabet-Google net profit. It also indicates that correlation between Alphabet-Google net profit (Y) in Viet Nam and lending rate and S\&P 500 in the US (0.9 and 0.8) is higher than that between Y and GDP growth $(0.25)$ or between Y and CPI $(0.16)$.

The below table 3 shows us that covariance matrix among 8 macro economic variables. Alphabet-Google net profit (Y) has a positive correlation with CPI, and GDP growth.

Hence, an increase in inflation may have slight positive impact on in Alphabet-Google net profit.

Table 3: Covariance Matrix for 8 Macro Economic Variables

\begin{tabular}{|c|c|c|c|c|c|c|c|c|}
\hline \multicolumn{9}{|c|}{ Covariance Matrix } \\
\hline & Y & NETSALE & STOCKPRICE & SP500 & R & G & CPI & COST \\
\hline Y & 69.85000 & 314.6000 & 2758.553 & 4086.063 & 0.054390 & 0.966000 & 0.874500 & 147.3000 \\
\hline NETSALE & 314.6000 & 1715.840 & 15235.39 & 24028.01 & 0.276984 & 4.336200 & 5.396200 & 793.5400 \\
\hline STOCKPRICE & 2758.553 & 15235.39 & 140445.1 & 210841.0 & 2.452156 & 53.37353 & 38.59157 & 7037.243 \\
\hline SP500 & 4086.063 & 24028.01 & 210841.0 & 361545.2 & 3.597767 & 47.94057 & 36.41678 & 11011.49 \\
\hline R & 0.054390 & 0.276984 & 2.452156 & 3.597767 & $5.16 E-05$ & 0.000833 & 0.001660 & 0.130924 \\
\hline G & 0.966000 & 4.336200 & 53.37353 & 47.94057 & 0.000833 & 0.211956 & -0.181704 & 2.065200 \\
\hline CPI & 0.874500 & 5.396200 & 38.59157 & 36.41678 & 0.001660 & -0.181704 & 0.415841 & 2.741200 \\
\hline COST & 147.3000 & 793.5400 & 7037.243 & 11011.49 & 0.130924 & 2.065200 & 2.741200 & 368.2400 \\
\hline
\end{tabular}




\section{Regression Model and Main Findings}

In this section, we will find out the relationship between eight macro economic factors and public debt.

Scenario 1: Regression model with single variable: analyzing impact of cost (c.o) on Alphabet-Google net profit $(\mathrm{Y})$

Note: C: constant

Using Eview gives us the below results:

\begin{tabular}{|c|c|c|c|c|}
\hline \multicolumn{5}{|c|}{$\begin{array}{l}\text { Dependent Variable: } Y \\
\text { Method: Least Squares } \\
\text { Date: } 02 / 26 / 20 \text { Time: } 11: 34 \\
\text { Sample: } 110 \\
\text { Included observations: } 10\end{array}$} \\
\hline Variable & Coefficient & Std. Error & t-Statistic & Prob. \\
\hline COST & 0.400011 & 0.060907 & 6.567559 & 0.0002 \\
\hline $\mathrm{C}$ & 3.539648 & 2.293538 & 1.543313 & 0.1613 \\
\hline R-squared & 0.843545 & \multicolumn{2}{|c|}{ Mean dependent var } & 16.50000 \\
\hline Adjusted R-squared & 0.823988 & \multicolumn{2}{|c|}{ S.D. dependent var } & 8.809717 \\
\hline S.E. of regression & 3.696011 & \multicolumn{2}{|c|}{ Akaike info criterion } & 5.629242 \\
\hline Sum squared resid & 109.2840 & \multicolumn{2}{|c|}{ Schwarz criterion } & 5.689759 \\
\hline Log likelihood & -26.14621 & \multicolumn{2}{|c|}{ F-statistic } & 43.13283 \\
\hline Durbin-Watson stat & 2.576761 & \multicolumn{2}{|c|}{ Prob(F-statistic) } & 0.000175 \\
\hline
\end{tabular}

Hence, $\mathrm{Y}=0.4 * \operatorname{COST}+3.5, \mathrm{R}^{2}=0.84 \mathrm{SER}=3.6$

Within the range of 10 observations (2014-2019) as described in the above scatter chart 1, coefficient 0.4, when cost increases, Alphabet-Google net profit. Will increase.

Scenario 2 - Regression model with 2 variables: analyzing impact of Inflation (CPI) on Alphabet-Google net profit:

Running Eview gives us below results:

\begin{tabular}{|c|c|c|c|c|}
\hline \multicolumn{5}{|c|}{$\begin{array}{l}\text { Dependent Variable: } Y \\
\text { Method: Least Squares } \\
\text { Date: } 02 / 26 / 20 \text { Time: } 11: 35 \\
\text { Sample: } 110 \\
\text { Included observations: } 10\end{array}$} \\
\hline Variable & Coefficient & Std. Error & t-Statistic & Prob. \\
\hline $\mathrm{CPI}$ & -0.561431 & 1.975607 & -0.284182 & 0.7845 \\
\hline COST & 0.404190 & 0.066389 & 6.088173 & 0.0005 \\
\hline $\mathrm{C}$ & 4.390673 & 3.861496 & 1.137039 & 0.2929 \\
\hline R-squared & 0.845329 & \multirow{6}{*}{\multicolumn{2}{|c|}{$\begin{array}{l}\text { Mean dependent var } \\
\text { S.D. dependent var } \\
\text { Akaike info criterion } \\
\text { Schwarz criterion } \\
\text { F-statistic } \\
\text { Prob(F-statistic) }\end{array}$}} & 16.50000 \\
\hline Adjusted R-squared & 0.801138 & & & 8.809717 \\
\hline S.E. of regression & 3.928605 & & & 5.817771 \\
\hline Sum squared resid & 108.0376 & & & 5.908547 \\
\hline Log likelihood & -26.08885 & & & 19.12870 \\
\hline Durbin-Watson stat & 2.591892 & & & 0.001455 \\
\hline
\end{tabular}

Therefore, $\mathrm{Y}=0.4 * \operatorname{COST}-0.5 * \mathrm{CPI}+4.3, \mathrm{R}^{2}=0.84, \mathrm{SER}=3.9$ 
Hence, this equation shows us Alphabet-Google net profit has a positive correlation with COST and negative relationship with inflation in US. Esp., it is more negatively affected by CPI.

Scenario 3 - Regression model with 3 variables: adding GDP growth (g) into the above model

Eviews generates below statistical results :

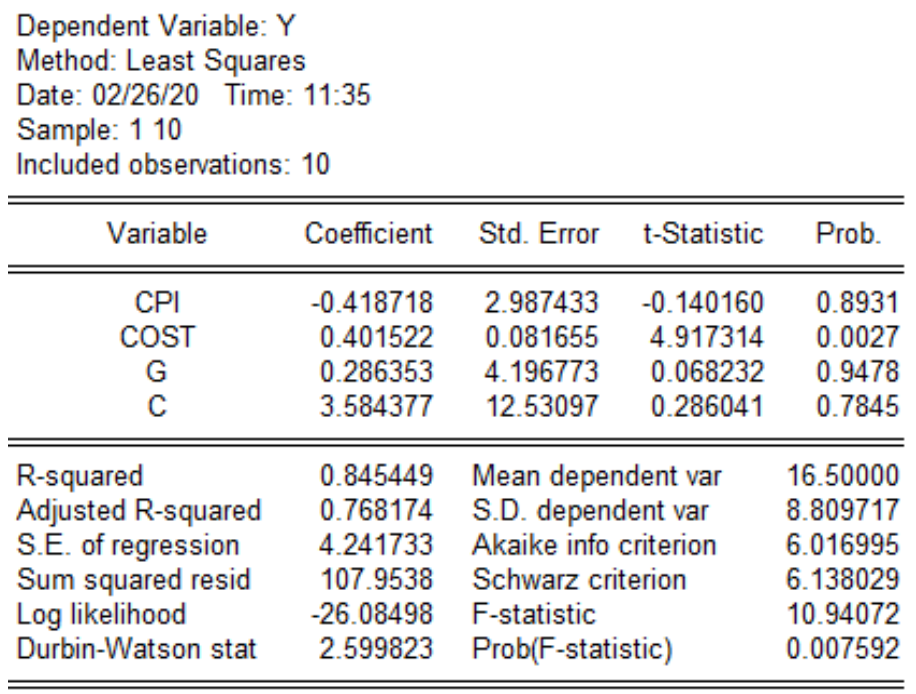

Hence, $\mathrm{Y}=0.28 * \mathrm{G}-0.4 * \mathrm{CPI}+0.4 * \mathrm{COST}+3.5, \mathrm{R}^{2}=0.84, \mathrm{SER}=4.2$

The above regression equation shows us that Alphabet-Google net profit (Y) has a positive correlation with GDP growth $(\mathrm{G})$ and cost, but negative relationship with inflation (CPI). And the coefficient (with cost and CPI) is the highest, the $2^{\text {nd }}$ highest is with GDP growth. CPI increases will increase costs of business and lead to a decrease in AlphabetGoogle net profit.

Scenario 4 - regression model with 5 macro and micro variables: adding sale into the above model:

Eviews presents the below results:

Dependent Variable: $Y$

Method: Least Squares

Date: $02 / 26 / 20$ Time: $11: 36$

Sample: 110

Included observations: 10

\begin{tabular}{crlll}
\hline \hline Variable & Coefficient & Std. Error & t-Statistic & Prob. \\
\hline \hline CPI & -2.860304 & 3.547480 & -0.806292 & 0.4567 \\
COST & 2.137499 & 1.464427 & 1.459614 & 0.2042 \\
G & -2.565194 & 4.717794 & -0.543727 & 0.6100 \\
NETSALE & -0.789720 & 0.665218 & -1.187160 & 0.2885 \\
C & 21.51523 & 19.36820 & 1.110853 & 0.3172 \\
\hline \hline R-squared & 0.879433 & Mean dependent var & 16.50000 \\
Adjusted R-squared & 0.782980 & S.D. dependent var & 8.809717 \\
S.E. of regression & 4.104044 & Akaike info criterion & 5.968676 \\
Sum squared resid & 84.21590 & Schwarz criterion & 6.119968 \\
Log likelihood & -24.84338 & F-statistic & 9.117697 \\
Durbin-Watson stat & 2.928031 & Prob(F-statistic) & 0.016145 \\
\hline \hline
\end{tabular}

Therefore, $\mathrm{Y}=-2.5 * \mathrm{G}-2.8 * \mathrm{CPI}+2.13 * \mathrm{COST}-0.7 * \mathrm{NETSALE}+21.5, \mathrm{R}^{2}=0.87, \mathrm{SER}=4.1$ 

A Case of Alphabet \& Google in the US

We find out impacts of 4 macro variables, with the new factor: SALE, shown in the above equation, AlphabetGoogle net profit (Y) has negative correlation with GDP growth and inflation and net sale, whereas it has positive correlation with Cost. When inflation goes down, cost increases, this will increase public investment in stock market, as a result, Alphabet-Google net profit will increase.

Scenario 5 - regression model with 7 macro and micro variables: adding Alphabet stock price ont the above model.

Running Eviews gives us results:

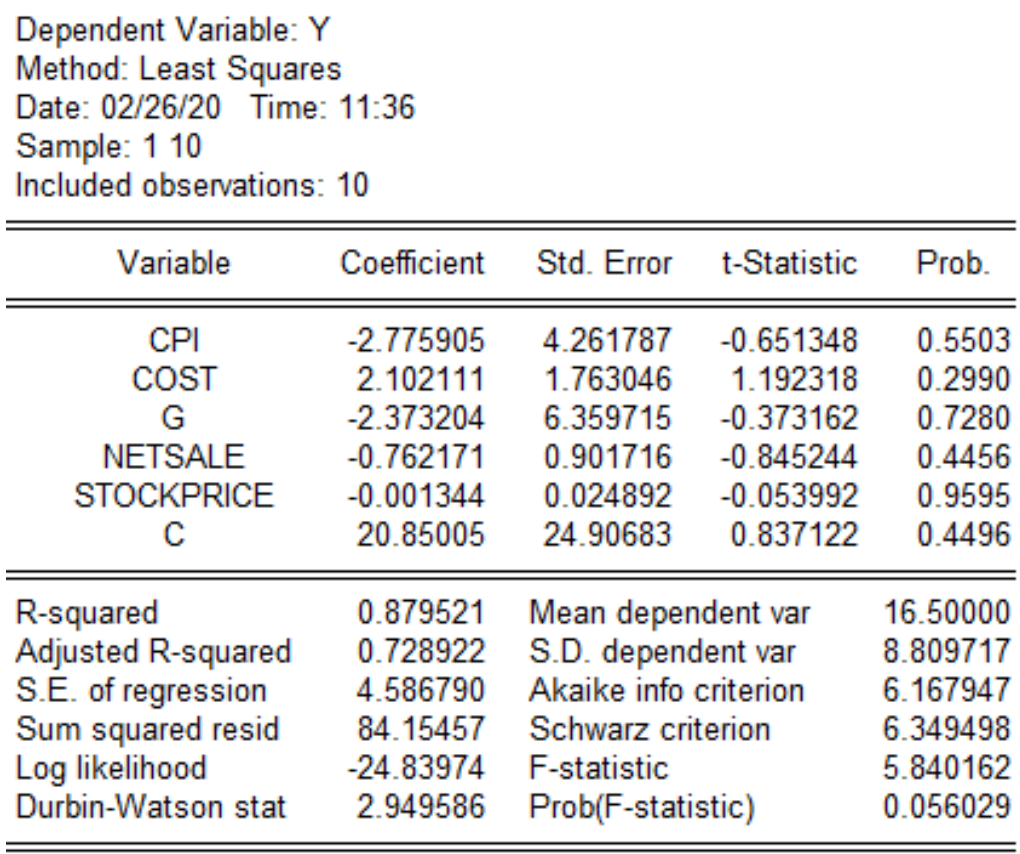

Hence, $\mathrm{Y}=-2.3 * \mathrm{G}-2.7 * \mathrm{CPI}+2.1 * \mathrm{COST}-0.7 * \mathrm{NETSALE}-0.001 * \mathrm{STOCKPRICE}+20.8, \mathrm{R}^{2}=0.87, \mathrm{SER}=$ 4.5

Here we see impacts of 5 macro factors, with the new variable: STOCK PRICE, the above equation shows that Alphabet-Google net profit (Y) has negative correlation with GDP growth and inflation, stock price and net sale, whereas it has positive correlation with cost. We also recognize that GDP growth and CPI have the highest impact on AlphabetGoogle net profit. When cost declines, it implies less production, then it will lead to a decrease in Alphabet-Google net profit.

Scenario 6 - regression model with 8 macro variables: adding S\&P500 onto the above model.

Running Eviews gives us results: 


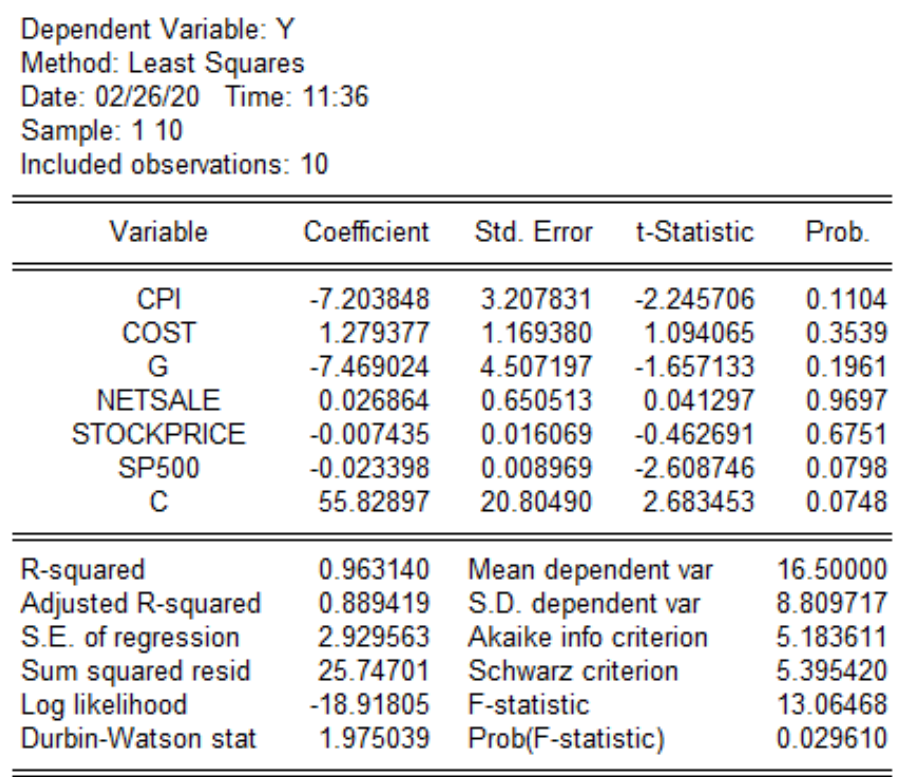

$$
\begin{array}{r}
\mathrm{Y}=-7.4 * \mathrm{G}-7.2 * \mathrm{CPI}+1.2 * \mathrm{COST}+0.02 * \mathrm{NETSALE}-0.007 * \mathrm{STOCKPRICE}-0.02 * \mathrm{SP} 500+55.8, \\
\mathrm{R}^{2}=0.96, \mathrm{SER}=2.9
\end{array}
$$

Therefore, we see impacts of 6 macro factors, with the new variable: SP500, the above equation shows that Alphabet-Google net profit (Y) has negative correlation with GDP growth, inflation, stock price and SP500, whereas it has positive correlation with cost and net sale. We also recognize that GDP growth and cost, then CPI have the highest impact on Alphabet-Google net profit, while stock price just has a slightly impact on stock price.

Scenario 7 - regression model with 7 macro variables: adding lending rate (r) onto the above model.

\begin{tabular}{|c|c|c|c|c|}
\hline $\begin{array}{l}\text { Dependent Variable } \\
\text { Method: Least Squa } \\
\text { Date: } 02 / 26 / 20 \text { Tim } \\
\text { Sample: } 110 \\
\text { Included observation }\end{array}$ & $11: 37$ & & & \\
\hline Variable & Coefficient & Std. Error & t-Statistic & Prob. \\
\hline $\mathrm{CPI}$ & -7.904407 & 7.153141 & -1.105026 & 0.3843 \\
\hline Cost & 0.505225 & 6.767510 & 0.074654 & 0.9473 \\
\hline G & -8.206656 & 8.366327 & -0.980915 & 0.4301 \\
\hline NETSALE & 0.315175 & 2.588453 & 0.121762 & 0.9142 \\
\hline STOCKPRICE & -0.007195 & 0.019720 & -0.364877 & 0.7502 \\
\hline SP500 & -0.023189 & 0.011092 & -2.090599 & 0.1717 \\
\hline $\mathrm{R}$ & 425.7805 & 3638.375 & 0.117025 & 0.9175 \\
\hline C & 44.19786 & 102.5828 & 0.430851 & 0.7086 \\
\hline R-squared & 0.963390 & Mean dep & lent var & 16.50000 \\
\hline Adjusted R-squared & 0.835256 & S.D. depe & dent var & 8.809717 \\
\hline S.E. of regression & 3.575745 & Akaike info & criterion & 5.376786 \\
\hline Sum squared resid & 25.57191 & Schwarz cr & terion & 5.618855 \\
\hline Log likelihood & -18.88393 & F-statistic & & 7.518608 \\
\hline Durbin-Watson stat & 2.049687 & Prob(F-stat & stic) & 0.122377 \\
\hline
\end{tabular}

Running Eviews gives us results:

$\mathrm{Y}=-8.2 * \mathrm{G}-7.9 * \mathrm{CPI}+425 * \mathrm{R}-0.02 * \mathrm{SP} 500+0.5 * \mathrm{COST}+0.3 * \mathrm{NETSALE}-0.007 * \mathrm{STOCKPRICE}+44.1$

$$
\mathrm{R}^{2}=0.96, \mathrm{SER}=3.5
$$



A Case of Alphabet \& Google in the US

Therefore, we see impacts of 7 micro and macro factors, with the new variable: lending rate $\mathrm{R}$, the above equation shows that ALPHABET net profit (Y) has negative correlation with GDP growth, inflation, SP500 and stock price, whereas it has positive correlation with cost, net sale, lending rate. We also recognize that GDP growth and lending rate, then CPI have the highest impact on Google-Alphabet net profit, while SP500 and stock price just has a slightly impact on net profit.

\section{DISCUSSION AND FURTHER RESEARCHES}

Through the regression equation with above 7 micro and macroeconomic variables, this research paper used updated data from 2014-2019 to analyze the regression equation via Eview in order to show that an increase in GDP growth has a significant impact on reducing Alphabet-Google net profit (Y) with the highest coefficient of impact, followed by a decrease in lending rate and increase in inflation, then an increase in SP500, and decrease in cost and net sale.

Data are from observations in the past 10 years, it is partly based on the market economic rules, and the research results are also affected by socio-economic characteristics in US such as: efficiency of public investment, waste of public investment, enterprise bankruptcy, and investment in areas that increase GDP such as production, electricity, etc. or investing in healthcare, environment and education sectors. We have not yet considered the impact of these factors.

Beside, we can analyze impact of another macro factor, for example, deposit rate when we add this variable into our regression model of public debt. Furthermore, we can add unemployment rate or public debt increase into our econometric model to measure the impact of these extra factors on Alphabet-Google net profit.

\section{Other Issues of the Discussed Topic Concern the Development of New Technologies and the Shaping of Cybersecurity Policy}

With the development of Industry 4.0, cyberattacks on innovative ICT technologies can be a fundamental problem, which is why networks and information systems of the combined economy, society or critical infrastructure in the era of digitization require ever stronger and efficient security. Determining the basic safety recommendations for Industry 4.0 components, services, and processes based on risk analysis is the first step to resolve difficult technical constraints in this field. Therefore, several basic recommendations should be made regarding the improvement of cybersecurity risk management standards in the development of new ICT technologies. These recommendations are only the basis for undertaking further analyzes of the subject taken. Ensuring a uniform and stable legal environment for cybersecurity of ICT Industry 4.0 will enable companies to plan long-term, sustainable business strategies, including improving various legal, organizational and technological aspects related to cybersecurity. Developing certification systems for ICT Industry 4.0 security technologies will make the market harmonization process more effective, increase consumer confidence and open new business opportunities. From a procedural point of view, recent jurisdictional cases in the US and EU have shown the difficulties faced by victims of cybercrime due to the different criminal law provisions on cyber attacks. According to J. Siegel (When The Internet of Things Flounders: Looking Into Gdpr-Esque Security Standards for IoT Devices in The United States From The Consumers' Perspective) in the US, the lack of a definition of "data breach" through cyber incidents leads to high uncertainty about this how consumers can protect themselves effectively when using new ICT. Federal legislation in the United States revolving around cybersecurity (whether it will be guidelines for companies, specific industries, the government, or whether it concerns, for example, how to notify consumers if they are victims of a data breach) is extremely dispersed and unclear. Because federal legislation in the United States is ad hoc, and 
different industries and areas of activity are supported by different pieces of legislation rather than one general branch or statute, consumers affected by a data breach have difficulty determining what pieces of legislation to rely on. Compared to federal regulations, each of the fifty states has its way of dealing with data breaches. Regulation (EU) 2016/679 of the European Parliament and of the Council of 27 April 2016 on the protection of natural persons concerning the processing of personal data and the free movement of such data, and repealing Directive 95/46 / The EC (General Data Protection Regulation) in force since May 2018 in the Member States of the European Union allows consumers to demand the deletion of their data from the hands of businesses, requires companies to notify consumers of a violation of their data and clearly defines the consequences for companies who do not comply with the rules about personal data protection. The GDPR already has an impact on international corporations because they must ensure that their activities comply with the requirements of the GDPR to be able to do business in the European Union and legally process clients' data. Theoretically, this legal protection of personal data applies to the data of EU citizens, but the global nature of the Internet means that this legal obligation will apply to all online services, and the regulation has already caused significant changes for US users as companies try to adapt to them. Therefore, due to the adoption in the United States of legislation similar to European Union's GDPR, combined with the legal definition of cybersecurity standards and certification for devices and networks used by users, e.g. in IoT, will improve the actual cross-border protection of data and information and network and IT systems.

\section{CONCLUSIONS AND POLICY SUGGESTION}

Based on the above data analysis from our regression model, for better managing Alphabet-Google net profit., we would suggest the Governmental bodies, FED and bank system also need to apply macro policies to stimulate economic growth, however not decreasing lending rate too much, together with credit, operational and market risk management, corporate governance and controlling bad debt.

Next, it is necessary to limit the negative effects of lending rate i.e not increasing much. Lending policy of bank system need to be selective and increase interest rates for acceptable high risk high return projects.

Generally speaking, managing Alphabet-Google net profit depends on many factors, so the government need to use fiscal policy combined with monetary policies and socio-economic policies to reduce unemployment and stimulate economic growth, toward a good net profit management. For Google management, it is good to increase cost and sale volumn.

Corporate investment in cybersecurity is also an important issue.

European Parliament Resolution (2017) on the fight against cybercrime emphasizes the rapid increase in the number of ransomware, botnets and unauthorized breaches of computer systems, affecting not only the security, availability, and integrity of their data personal protection, protection of privacy and fundamental freedoms, but also on the integrity of the infrastructure of financial structures, such as banks or stock exchanges. Gartner reports (Digital Transformation Innovation, 2020) predict that from 2020, over 25\% of cyber attacks identified in enterprises will affect IoT and this percentage will increase. The desire to obtain information on new ICT technologies and business development plans will increase, which may cause increased cyberattacks on networks and information systems. Therefore, the development of ICT, faster industrial networks and 5G technology mean that solutions for security against cyber threats 
should at the same time develop and keep up with the effectiveness of protecting networks and information systems by institutions.

\section{ACKNOWLEDGEMENTS}

I would like to take this opportunity to express my warm thanks to Board of Editors and my colleagues, and brother in assisting convenient conditions for my research paper.

\section{REFERENCES}

1. Ahmad, N., \& Ramzan, M. (2016). Stock Market Volatility and Macroeconomic Factor Volatility, International Journal of Research in Business Studies and Management, 3(7), 37-44.

2. Arshad, Z., Ali, R. A., Yousaf, S., \& Jamil, S. (2015). Determinants of Share Prices of listed Commercial Banks in Pakistan, IOSR Journal of Economics and Finance, 6(2), 56-64.

3. Ayub, A., \& Masih, M. (2013). Interest Rate, Exchange Rate, and Stock Prices of Islamic Banks: A Panel Data Analysis, MPRA Paper No. 58871.

4. Cherif, R., \& Hasanov, F. (2012). Public Debt Dynamics: The Effects of Austerity, Inflation, and Growth Shocks, IMF Working paper WP/12/230

5. Digital Transformation Innovation. Gartner, Germany 2020

6. European Parliament Resolution of 3 October 2017 on the fight against cybercrime (2017/2068 (INI))

7. Huy, D.T.N. (2013). Beta of Viet Nam Listed Computer and Electrical Company Groups During and After The Financial Crisis 2007-2011, Asian Journal of Finance \& Accounting, 5(1).

8. Industry 4.0 Cybersecurity. Challenges \& Recommendations, European Union Agency for Network and Information Security, ENISA, May 2019.

9. Krishna, R.C. (2015). Macroeconomic Variables impact on Stock Prices in a BRIC Stock Markets: An Empirical Analysis, Journal of Stock \& Forex Trading, 4(2).

10. Kulathunga, K. (2015). Macroeconomic Factors and Stock Market Development: With Special Reference to Colombo Stock Exchange, International Journal of Scientific and Research Publications, 5(8), 1-7.

11. Ihsan, H., Ahmad, E., Muhamad, I.H., \& Sadia, H. (2015). International Journal of Scientific and Research Publications, 5(8)

12. Jarrah, M., \& Salim, N. (2016). The Impact of Macroeconomic Factors on Saudi Stock Market (Tadawul) Prices, Int'l Conf. on Advances in Big Data Analytics.

13. Luthra, M., \& Mahajan, S. (2014). Impact of Macro factors on BSE Bankex, International Journal of Current Research and Academic Review, 2(2), 179-186.

14. Ndlovu, M., Faisal, F., Nil, G.R., \& Tursoy, T. (2018).The Impact of Macroeconomic Variables on Stock Returns: A Case of the Johannesburg Stock Exchange, Romanian Statistical Review, 2, 88-104.

15. Pan, Q., \& Pan, M. (2014). The Impact of Macro Factors on the Profitability of China's Commercial Banks in the Decade after WTO Accession, Open Journal of Social Sciences, 2, 64-69.

16. Regulation (EU) 2016/679 of the European Parliament and of the Council of 27 April 2016 on the protection of natural persons with regard to the processing of personal data and on the free movement of such data, and repealing Directive 95/46/EC (General Data Protection Regulation). 
17. Siegel J. (2020), When The Internet of Things Flounders: Looking Into Gdpr-Esque Security Standards for Iot Devices in The United States From The Consumers' Perspective, Journal of High Technology Law, Vol. XX: No. 1, 2020.

18. Saeed, S., \& Akhter, N. (2012). Impact of Macroeconomic Factors on Banking Index in Pakistan, Interdisciplinary Journal of Contemporary Research in Business, 4(6), 1200-1218.

19. https://www.sbv.gov.vn

20. https://nif.mof.gov.vn

21. Al-Ethary, Adnan Dawood M., Myieh Shbeeb Al-Shamri, and Sadek Ali Taan Al-Jobory. "The Impact of economic openness degree on GDP growth in Malaysia and some neighboring countries for the period 1990-2010." International Journal of Business and General Management (IJBGM) 3.2 (2014):57- 74.

22. Khan, Ruby. "Economic Growth Stimulation Under VAT or GST Regime; Case Study of Saudi Arabia and India." International Journal of Economics, Commerce and Research (IJECR) 10.2 (2020): 17-28.

23. Buche, Anish. "Factors Affecting Volatility in Indian Stock Markets." International Journal of Financial Management (IJFM) 5.3 (2016): 1-8.

24. Das, Saugat, and Ankit Agarwal. "Optimal Portfolio Construction of Pharmaceutical Companies-A Study on Cnx Pharma Index." International Journal of Accounting and Financial Management Research (IJAFMR) 4.3 (2014): 1-4. 